\title{
腎臟ノ Histamin.
}

\section{第 2 篇 所謂腎臟毒注射時ニ於ヶル 腎藏 Histamin 量ノ消長}

Sh. Yamada: Histamin in Niere.

II. Mitteilung: Über die Schwankungen von Histaminmenge in der mit verschiedenen Nierengiften geschädigten Nieren.

\author{
金摆醫科大學皮成科泌尿器科呚室 (主任 並木敉授) \\ 專攻生 醫 學士 山田 祥 二
}

(本㻅交ノ要旨ハ昭和18年 3 月第32回日本泌尿器利學會總會ニテ發表シタ)

緒論

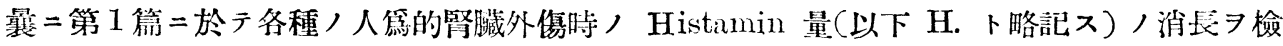

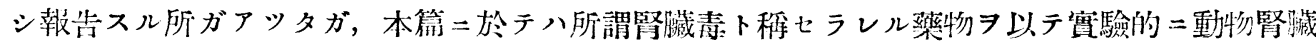

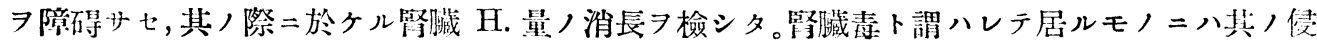

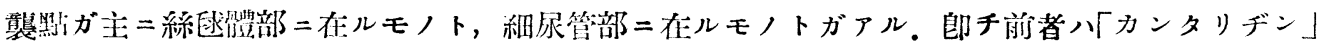

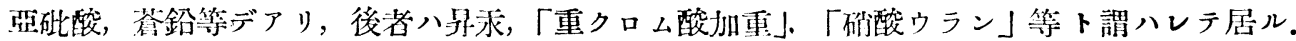

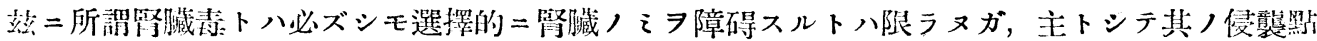

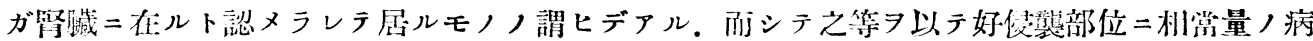

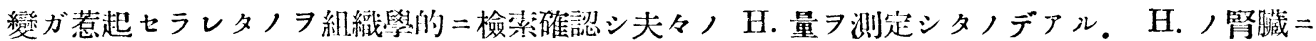

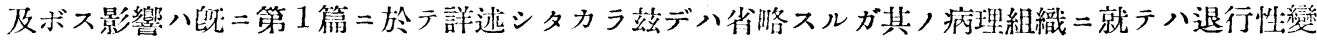
化ヨ細尿管部二惹起スルガ綵昶體ニ八何等ノ變化ヨモ起サナイト一般ニ報告サレテ居ル．然シ

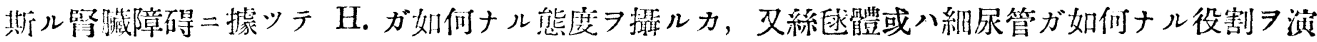

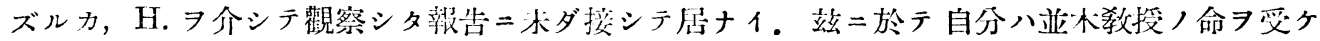

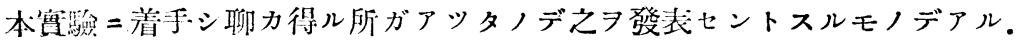

\section{第 1 章 白鼠腎ノ H. 量二對ス几腎臟毒ノ影響}

\section{實驗方法}

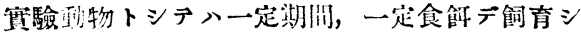
夕娟重 $100 \mathrm{~g}$ 前後ノ白鼠及ビ $20 \mathrm{~g}$ 前後

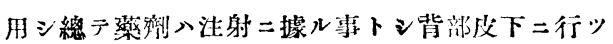

タ、而シテ夫々ノ注射量二達シタナラ之レチ㨙殺 シテ计チ二督践キ剔山シ H. 定量操作二移ツタ. 勿諭斯ル手術操作二際シテカ消毒キ噘重こシ雜菌 二幏ル II. 生成キ防ギ密色殺菌劑入比色ノ妨害キ 
恐レテ㑛月シナカツタII. 定昷法ハ横山氏法二從 ツテ分離シタII. キ原法ノ如キ比色法二幏ラプ第

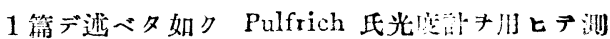
定シタ。

\section{第 1 莭 正常白鼠ノ腎 H. 量}

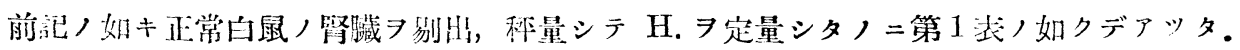

第 1 表 正管白鼠腎H. 量

\begin{tabular}{|c|c|c|c|c|c|c|}
\hline $\begin{array}{l}\text { 番 } \\
\text { 號 }\end{array}$ & 娟 $\mathrm{g}$ 重 & $\begin{array}{l}\text { 定量二用七 } \\
\text { 及㹂重 } \mathrm{g}\end{array}$ & $2 \mathrm{E}$ & $\mathrm{mg} / \mathrm{kgH}$. & $\begin{array}{c}\text { 平均值 } \exists y \text { 人偏佮 } \\
\mathrm{v}\end{array}$ & $v^{2}$ \\
\hline 1 & 134 & 1.5 & 0.20 & 0.52 & +0.04 & 0.0016 \\
\hline 2 & 79 & 1.0 & 0.10 & 0.45 & -0.03 & 0.0009 \\
\hline 3 & 83 & 1.0 & 0.18 & 0.75 & +0.27 & 0.0729 \\
\hline 4 & 82 & 1.0 & 0.10 & 0.45 & -0.03 & 0.0009 \\
\hline 5 & 103 & 1.0 & 0.02 & 0.10 & -0.38 & 0.1444 \\
\hline 6 & 120 & 1.0 & 0.18 & 0.75 & +0.27 & 0.0729 \\
\hline 7 & 80 & 1.0 & 0.16 & 0.67 & +0.19 & 0.0361 \\
\hline 8 & 85 & 1.0 & 0.08 & 0.36 & -0.12 & 0.0144 \\
\hline 9 & 82 & 1.0 & 0.06 & 0.26 & -0.22 & $0.0+8 t$ \\
\hline 10 & 100 & 1.0 & 0.12 & 0.50 & +0.02 & 0.0002 \\
\hline
\end{tabular}

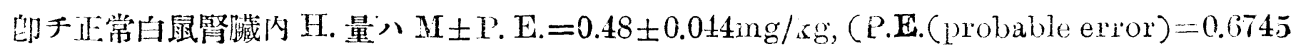
$\sqrt{\left.\frac{\Sigma\left(v^{2}\right)}{n(n-1)}\right)}, \sigma= \pm 0.20, V=41$ デアッタ.

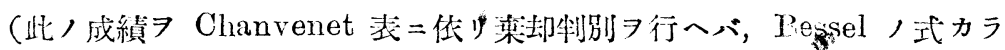

$$
\gamma=0.6745 \sqrt{\frac{\Sigma\left(v^{2}\right)}{n-1}}=0.141
$$

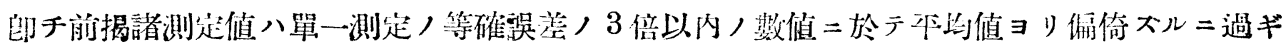
ザルガ故二總テラ包含シテ平均值フ出シタ）

\section{第 2 節腎臟毒/藥理並二惯驗成績}

\section{1. 昇录}

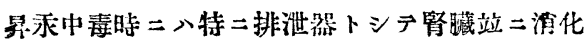
哭キ侵シ次デ中樞神經系症狀キ呈スルモノデ其ノ 作用機䡚入會 其八凝固性旮進二基ク血栓形成斗重視シ，Elbe

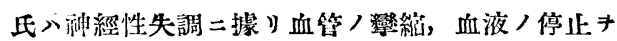
來ス二因り惹起サレルト謂七，Klempere 氏八寧 口該事物/话接作用二據り細胞/鉬死キ來入モ, ト速へタ。腎臟二於テ、Schlayer u. IJedinger, Takayasu, Folin, Karsner u. Denis, 鈴木, 池四

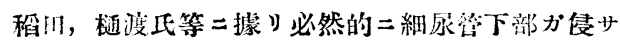
レル事キ明习カニシタガ何本其ノ毒力八强强，作

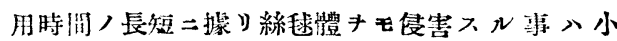
杉，相门自等／岻二指摘シタ所デアル。自分ハ本

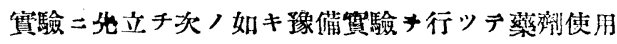

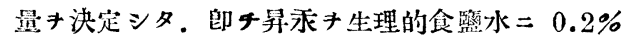
揢二溶カン種々ノ量ニ之レキ注射シ觀察スルニ 體重 $100 \mathrm{~g}=$ 就キ 0.3c.. ディ大部分ノモノガ生存
スル事斗識更二玟日 $0.3 \mathrm{ccc}$ 注射スル二次第二元

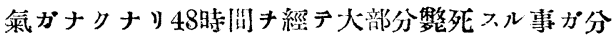
ッタノデ本賽驗デハ 0.3 c.c. 1 月 1 回, 2 月泊洼射 シ柆日之レキ摚殺シテ话チ二雨腎キ别出シII. 分 蜼操作子行フ事二シタ（勿諭多數賽騟山二八斯 ル藥量テ製死スルモノモアッタガ悉ク除外シタ).

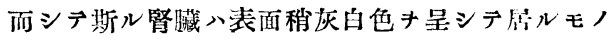
ガ多カッタ，倾ホ一部キ以き Zenker-formol 固定 「へマトキシリン，エォシン染色法」キ行七检镜ス $N=$ 細尿管下部上皮細胞八胞體腫大三，細胞限界 不明㙞トナッ，管㗪境界モ不明ノモノアッ，所二 幏ツテメ空胞キ形成》原形質ハ均一トナッテ扂

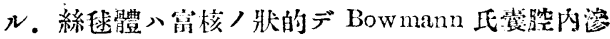
出物ノ㵔溜スルノガ認メヨレル。

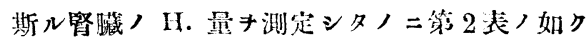
デアッタ.

即子前揭八如キ修件ノ下二昇永注射シタ白鼠 八腎內 II. 显八 M $\mathrm{M}$. E. $=0.60 \pm 0.035 \mathrm{mg} / \mathrm{kg}$ ， 


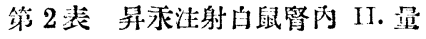

\begin{tabular}{|c|c|c|c|c|}
\hline 悉 號 & $\mathrm{g}^{\text {融 }}$ & 腎 & $2 \mathrm{E}$ & $\mathrm{mg} / \mathrm{kg} \mathrm{I}$. \\
\hline 1. & 64 & 1.0 & 0.20 & 0.80 \\
\hline 2 & 115 & 1.5 & 0.26 & 0.66 \\
\hline 3 & 67 & 1.0 & 0.10 & 0.45 \\
\hline 4 & 60 & 1.0 & 0.12 & 0.50 \\
\hline 5 & 65 & 1.0 & 0.10 & 0.45 \\
\hline 6 & 70 & 1.0 & 0.14 & 0.60 \\
\hline 7 & 110 & 1.0 & 0.24 & 0.92 \\
\hline 8 & 75 & 1.0 & 0.12 & 0.50 \\
\hline 9 & 60 & 1.0 & 0.18 & 0.75 \\
\hline 10 & 70 & 1.0 & 0.10 & 0.45 \\
\hline
\end{tabular}

$\sigma= \pm 0.18, \mathrm{~V}=30$ デアッタ.

\section{2.「イグロシン」}

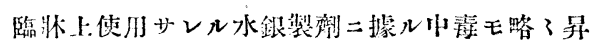
湬卜類スルモノト思ハレルガ弦デハ武回製有機性 水銀群「イグロシン」キ以テ筫驗キ行フ事ニシタ。

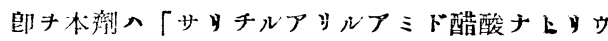
ム」ノ水銀化合澧ノ 10\%潩液卜「1:3ヂメチル キサンチン」ノ $3 \%$ 溶液トカヨナルモノデアル。

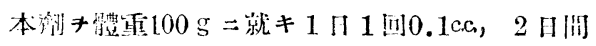

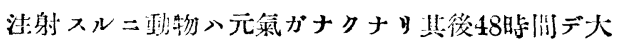
暗分ノモノが整死スル事筫識ツタノデ 2 回日注

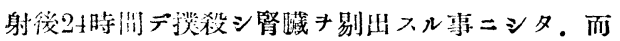

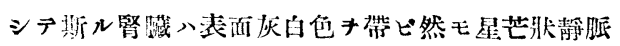
ハ著明トナッテ古ルモノガ多カツタ、之レキ檢鍤 スル二細越管細胞原形質入顆粗狀乃至網状卜ナリ

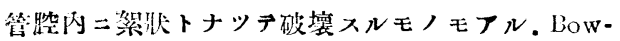

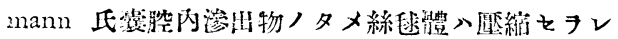

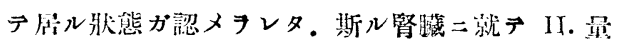
キ湘定シタノ二第 3 表ノ如クデアッタ.

第 3 表「イグロシン」注射白鼠腎内几。量

\begin{tabular}{|c|c|c|c|c|}
\hline 唀 號 & 散 & 䁂 & $2 \mathrm{E}$ & $\mathrm{mg} / \mathrm{kg} 1 \mathrm{H}$ \\
\hline 1 & 110 & 1.0 & 0.10 & 0.45 \\
\hline 2 & 160 & 1.5 & 0.20 & 0.52 \\
\hline 3 & 120 & 1.0 & 0.06 & 0.30 \\
\hline 4 & 100 & 1.0 & 0.12 & 0.50 \\
\hline 5 & 120 & 1.0 & 0.08 & 0.36 \\
\hline 6 & 95 & 1.0 & 0.16 & 0.67 \\
\hline 7 & 100 & 1.0 & 0.06. & 0.30 \\
\hline 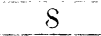 & 98 & 1.0 & 0.10 & 0.45 \\
\hline 9 & 95 & 1.0 & 0.10 & 0.45 \\
\hline 10 & 110 & 1.0 & 0.04 & 0.22 \\
\hline
\end{tabular}

印チ前損ノ條件ノ下ニ「イグロシン」注射シタ白 鼠留內 II. 是八N士P. E. $=0.42 \pm 0.028 \mathrm{mg} / \mathrm{kg}$, $\sigma= \pm 0.130, V=31$ デアッタ.

\section{3.「重クロム酸加里」}

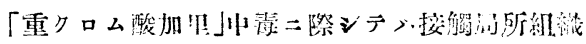

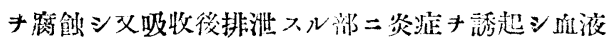
キ㻏シテ「メタへモグロピン」キ生ジ，心践; 肝藏

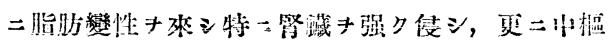

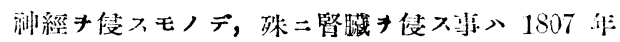

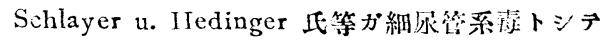

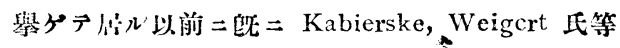

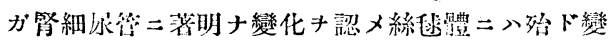

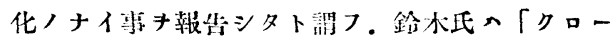

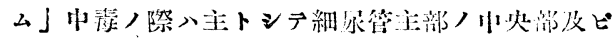

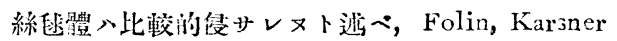

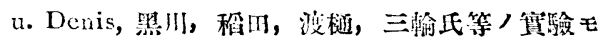

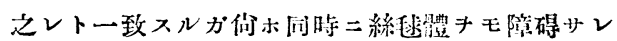
得ルハ免カレメ事赛デ小杉, 柯朋, 池地氏等入既 ニ之レキ證㛣シテ后ル。

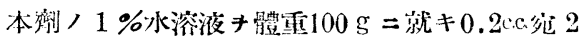

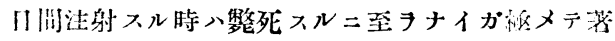
明二元策がナクナリ数日ま縃テ殆ド大补分ノもノ

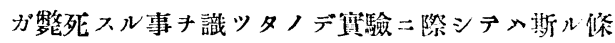

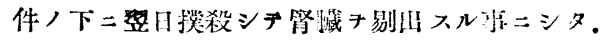

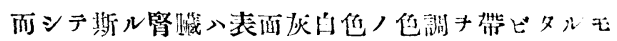

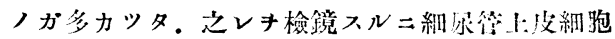

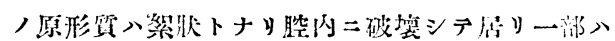

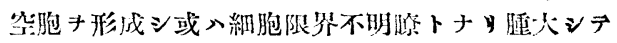

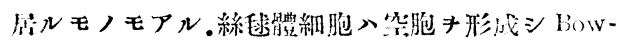

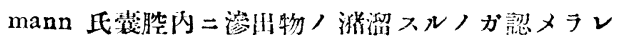

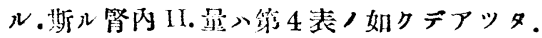

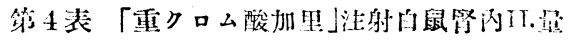

\begin{tabular}{|c|c|c|c|c|}
\hline 㥒 號 & 能 $\mathrm{g}$ & 腎 & $2 \mathrm{E}$ & $\mathrm{mg} / \mathrm{kg} \cdot \mathrm{I}$. \\
\hline 1 & 95 & 1.0 & 0.08 & 0.35 \\
\hline 2 & 98 & 1.0 & 0.22 & 0.85 \\
\hline 3 & 90 & 1.0 & $0.2)$ & 0.80 \\
\hline 4 & 100 & 1.0 & 0.04 & 0.21 \\
\hline 5 & 100 & 1.0 & $0.3 t$ & 2.00 \\
\hline 6 & 95 & 1.0 & 0.12 & 0.50 \\
\hline 7 & 100 & 1.0 & 0.22 & 0.85 \\
\hline 8 & 95 & 1.0 & 0.13 & 0.75 \\
\hline 9 & 90 & 1.0 & $0.0 \mathrm{~s}$ & 0.35 \\
\hline 10 & 95 & 1.0 & 0.28 & 1.20 \\
\hline
\end{tabular}

唧チ前揭ノ如キ條件二於テハ「重クロム酸加里」 洁射白鼠腎队， II. 最入 $\mathrm{M} \pm$ P.E. $=0.78 \pm 0.109$ 
$\mathrm{mg} / \mathrm{kg}, \sigma= \pm 0.30, \mathrm{~V}=50$ デケッタ,

\section{4.「カンタリヂン」}

「カンタリヂン」ハ其ノ排泄二際シ腺，漿液膜，

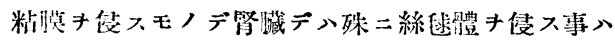
䓃クカヨ識タレ, そレキ明タカニシタノ、Schlayer u. Hedinger, Takayasu, Elliaschoff 氏等デ

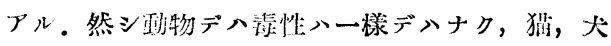
等八僅力數 $\mathrm{mg}$ デモ䌘死スルガ，彩等ノ如キハ30

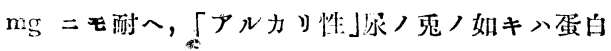

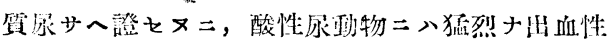

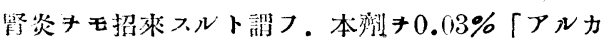
リ性」水溶液トナシ體重100 $\mathrm{g}=$ 就キ0.12c.c夗 I II

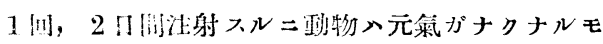
死二至ヨナイ故二斯ル修件ノ下二柆!之レキ提殺

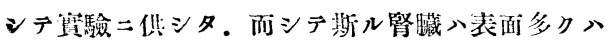

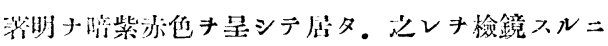

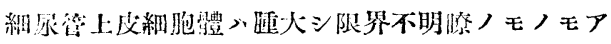

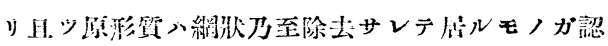

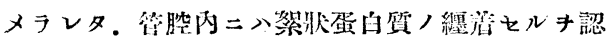

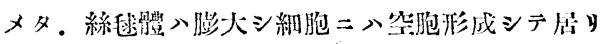

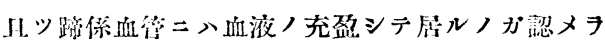

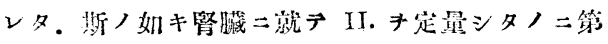
5 表ノ如クデアッタ.

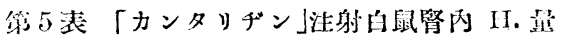

\begin{tabular}{|c|c|c|c|c|}
\hline 象 號 & 措 & 腎 $\mathrm{g}$ & $2 \mathrm{E}$ & $\mathrm{mg} / \mathrm{kg} \mathrm{II}$. \\
\hline I & 137 & 1.5 & 0.14 & 0.40 \\
\hline 2 & 132 & 1.2 & 0.10 & 0.37 \\
\hline 3 & 111 & 1.0 & 0.34 & 1.00 \\
\hline 4 & 95 & 1.0 & 0.12 & 0.50 \\
\hline 5 & 90 & 10 & 0.20 & 0.80 \\
\hline 6 & 90 & 1.0 & 0.22 & 0.85 \\
\hline 7 & 85 & 1.0 & 0.14 & 0.61 \\
\hline 8 & 85 & 1.0 & 0.14 & 0.60 \\
\hline 9 & 85 & 1.0 & 0.26 & 1.00 \\
\hline 10 & 95 & 1.0 & 0.18 & 0.75 \\
\hline
\end{tabular}

印于前揭ノ如キ條件ノ下二「カンタタヂン」キ注 射ンタ门鼠㹂內 II. 最入 $\mathrm{M} \pm$ P.E. $=0.68 \pm 0.048$ $\mathrm{mg} / \mathrm{h}, \sigma= \pm 0.24, \mathrm{~V}=35$ デフッタ.

\section{5.「硝酸ウラン」}

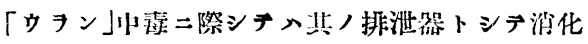
哭ノ炎症及ビ出血性㹂炎キ招來スルモノデ Chittenden u. Hambert 坁等ハ之レキ明 カカニシ， Schlayer u. IJedinger, Tessen, 樋洨氐等八細尿

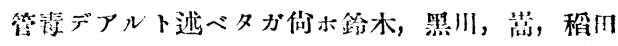

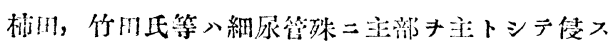
事キ明ヨカニシタガ问時二絲毯體キモ侵入事入无

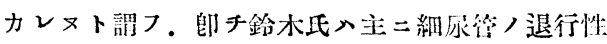

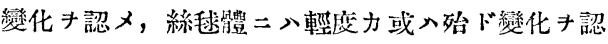

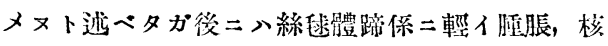
增生キ浔メテ㕍ル. Ophüls, Dickson, Christian, Smith, Baehr 烒等八動物實驗二於テ筒七皮ノ退

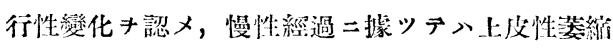

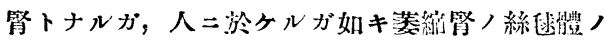

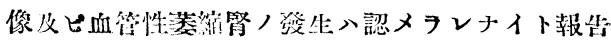
シテ原ル.

份木 Schlayer u. Hedinger 氏等、「カンタリ

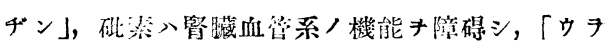
ン」,「クローム」, 势承等八機能的, 形黛的二モ

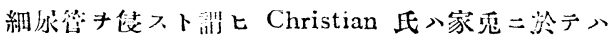

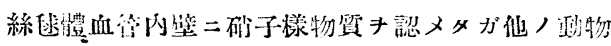

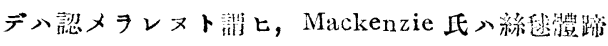

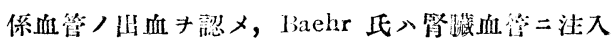
スレバ本數二變化ガ認メタレルト遮べ，池日氏八

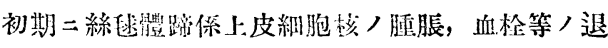

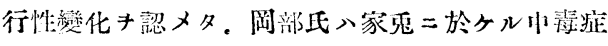

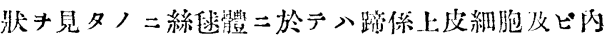

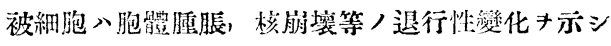

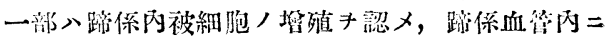
八多核白血球ノ藮程が認メタレタト述ベ，又所二

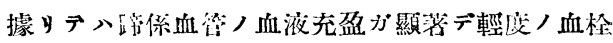

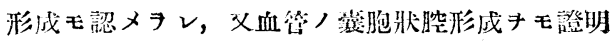

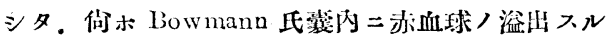
キ認メ，所二據リテ八落㧗擴大シ内二蛋白凝固物

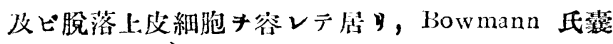

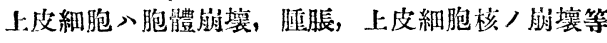
ノ退行性變化ガ認メタレ一部ニン上皮細胞ノ箸殖 モ認メラレ，份木殊二慢性經過キ㩑レルモノニ

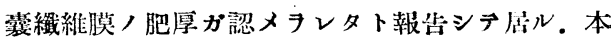

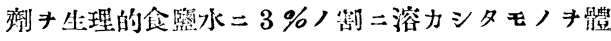
重100 g 二就 $\neq 1.0 \mathrm{ccc}$ 宛 1 日 1 回，2 日间注射スル 二㢦物ハ著明二元氣がナクナルガ死二至ラズ數「I 後ニハ大部分ノモノガ夥死スルニ至ル。仍テ斯ル 條件ノ下二注射シ柆日之レキ掽敉シテ萁驗二供ス ル事ニシタ．斯ル腎贜ハ表面ハ著明二星芒郝脈が 認メラレ且ツ一般二黄褐色ノ色調キ有スルチ篦ト シタ、而シテ之レチ檢鏡スルニ絲建體躘係上皮細

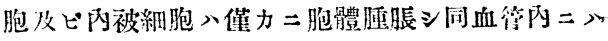


輕度ノ白血球ノ集程が認メラレ且 ツ Bowann 氏 露脿內

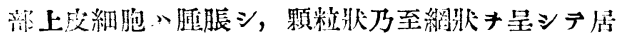

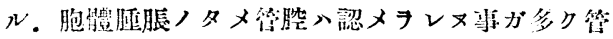

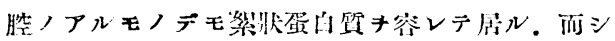

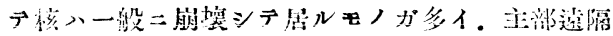

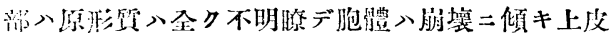
細胞核ハ染色性キ失ツテ居ル. Itenle 氏蹄保デハ

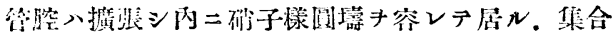

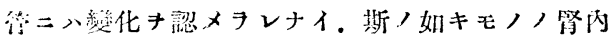

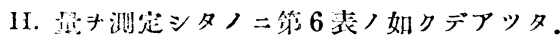

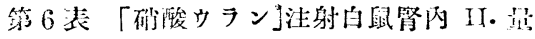

\begin{tabular}{|c|c|c|c|c|}
\hline 诱 跑 & $\mathrm{g}$ & ${ }_{\mathrm{g}}$ 等 & $2 \mathrm{E}$ & $\mathrm{mg} / \mathrm{kg}_{\mathrm{g}} \mathrm{II}$. \\
\hline 1 & 135 & 1.0 & 0.06 & 0.30 \\
\hline 2 & 115 & 1.0 & 0.02 & 0.10 \\
\hline 3 & 140 & 1.5 & 0.16 & 0.43 \\
\hline 4 & 88 & 1.0 & 0.06 & 0.30 \\
\hline 5 & 100 & 1.0 & 0.04 & 0.22 \\
\hline 6 & 95 & 1.0 & 0.10 & 0.45 \\
\hline$i$ & 125 & 1.0 & 0.04 & $0^{\circ} 22$ \\
\hline$s$ & 85 & 1.0 & 0.12 & 0.50 \\
\hline 9 & 100 & 1.0 & 0.02 & 0.10 \\
\hline 10 & 92 & 1.0 & 0.06 & 0.39 \\
\hline
\end{tabular}

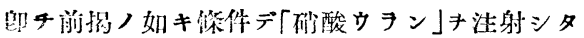

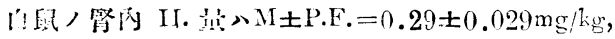
$c= \pm 0.13, \mathrm{~V}=44$ デアッタ.

\section{6. 亞䂣酸}

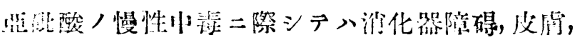

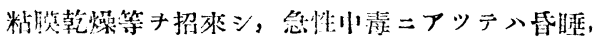
下樹「チフノーゼ」，皮府厥冷ヨリ死二至ルモ，斯

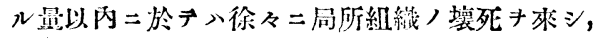
殊二㫮贜二於テハSchlayer u. Hedinger, Taka-

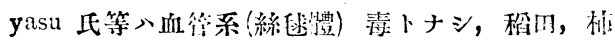

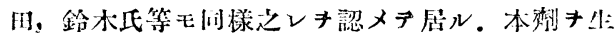

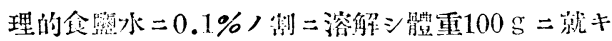

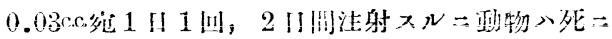

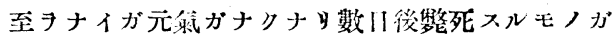

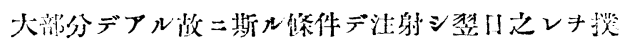

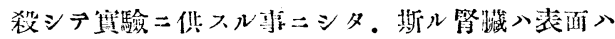

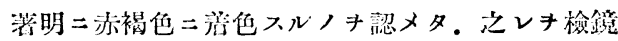
スル 細㞗管上皮細胞ノ核入染色惡ク原形質八綃

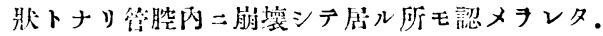

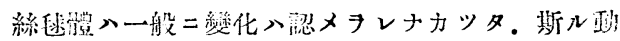

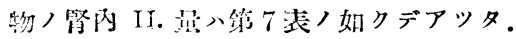

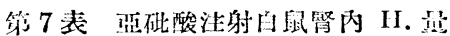

\begin{tabular}{|c|c|c|c|c|}
\hline 獣 謕 & 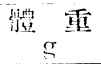 & 管 & $2 \mathrm{E}$ & $\mathrm{mg} / \mathrm{kg} \mathrm{II}$. \\
\hline 1 & 112 & 0.8 & 10.66 & 0.30 \\
\hline 2 & 100 & 1.0 & 0.02 & 0.10 \\
\hline 3 & 152 & 1.0 & 0.02 & 0.10 \\
\hline 4 & 83 & 1.0 & 0.10 & 0.45 \\
\hline 5 & 88 & 1.0 & 10.04 & 0.22 \\
\hline 6 & 110 & 1.0 & 0.06 & 0.30 \\
\hline 7 & 95 & 1.0 & 0.06 & 0.30 \\
\hline 8 & $8 S$ & 1.0 & (1).04 & 0.22 \\
\hline 9 & 95 & 1.0 & 0.02 & 0.10 \\
\hline 10 & 112 & 1.0 & 0.04 & 0.22 \\
\hline
\end{tabular}

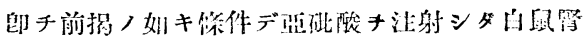
內 II. II: NI P.E. $=0.23 \pm 0.023 \mathrm{mg} / \mathrm{kg}, \sigma= \pm$ $0.108, \mathrm{~V}=46$ デアッタ.

\section{第 2 章 Maus 腎ノ H. 量ニ對ス几腎臟毒ノ影響}

\section{第 1 節 正常 Maus 腎 H. 量}

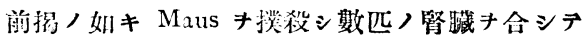

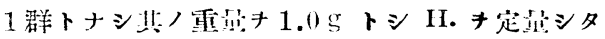
ノ二筷 9 表ノ如クデアッタ. (H. 定被檢材料 $1.0 \mathrm{~g}$ 以ドデ八操作二不便キ感ジタノデ斯ル方法

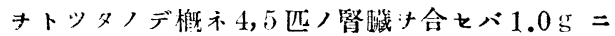

達スル事キ得タ)

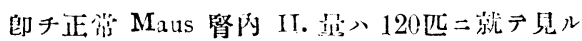
$=\mathrm{M} \pm$ P.E. $=0.83 \pm 0.074 \mathrm{mg} / \mathrm{kg}, \sigma= \pm 0.535$, $\mathrm{V}=64$ デアッタ. 们ホ $\gamma=0.392$ デアッタカフ總 テノ材料群き葉却スルコトナク探川シタ。

\section{第 2 節＼cjkstart腎臟毒ノ藥理並二實驗成績}

\section{1.〔カンタリヂン」}

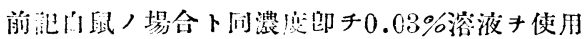

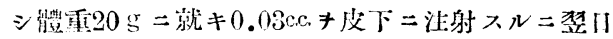

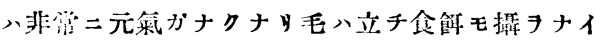

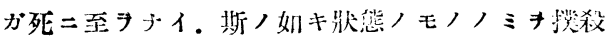

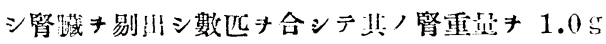
トナシ 1 群トシテ 11. 定星操作二移ツタ. 斯ノ刘

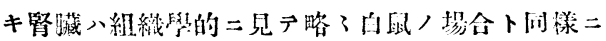




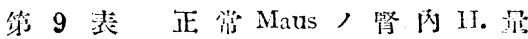

\begin{tabular}{|c|c|c|c|c|c|c|}
\hline $\begin{array}{l}\text { 采 } \\
\text { 视 }\end{array}$ & 匹 & $\begin{array}{l}\text { 定怗三用七 } \\
\text { 夕腎重 } 9\end{array}$ & $2 \mathrm{E}$ & $\mathrm{mg} / \mathrm{kg} \mathrm{I}$ & 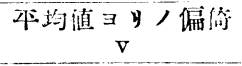 & $v^{2}$ \\
\hline 1 & 5 & 1.0 & 0.14 & 0.60 & -0.23 & 0.0529 \\
\hline$\ddot{z}$ & 4 & 1.0 & 0.14 & 0.60 & -0.23 & 0.0529 \\
\hline 3 & 4 & 1.0 & 0.24 & 0.93 & +0.10 & 0.0100 \\
\hline 4 & 4 & 1.0 & 0.06 & 0.27 & +0.57 & $0.32+9$ \\
\hline 5 & 4 & 1.0 & 0.44 & 2.90 & +2.07 & 4.2849 \\
\hline$b$ & 4 & 1.0 & 0.22 & 0.85 & +0.02 & 0.0004 \\
\hline 7 & 4 & 1.0 & 0.16 & 0.66 & -0.17 & 0.10289 \\
\hline$x$ & 4 & 1.0 & 0.14 & 0.60 & -0.23 & 0.0529 \\
\hline 9 & 5 & 1.0 & 0.38 & 2.50 & +1.67 & 2.7839 \\
\hline 10 & 5 & 1.0 & 0.20 & 0.80 & -0.03 & 0.0009 \\
\hline 11 & 4 & 1.0 & 0.16 & 0.66 & -0.17 & 0.0289 \\
\hline 12 & 4 & 1.0 & 0.16 & 0.66 & -0.17 & 0.0289 \\
\hline 13 & 5 & 1.0 & 0.08 & 0.28 & -0.55 & 0.3025 \\
\hline $1+$ & 4 & 1.0 & 0.10 & 0.45 & -0.38 & 0.1444 \\
\hline 15 & 4 & 1.0 & 0.20 & 0.80 & -0.03 & 0.0009 \\
\hline 19 & 5 & 1.0 & 0.16 & 0.66 & -0.17 & 0.0289 \\
\hline 17 & 4 & 1.0 & 0.14 & 0.60 & -0.23 & 0.0529 \\
\hline 18 & 5 & 1.0 & 0.26 & 1.00 & +0.17 & 0.0289 \\
\hline 19 & 5 & 1.0 & 0.08 & 0.28 & -0.55 & 0.3025 \\
\hline 20 & 5 & 1.0 & 0.12 & 0.50 & -0.33 & 0.1089 \\
\hline 21 & 5 & 1.0 & 0.12 & 0.50 & -0.33 & 0.1089 \\
\hline 22 & 5 & 1.0 & 0.20 & 0.80 & -0.03 & 0.0009 \\
\hline 23 & 4 & 1.0 & 0.22 & 0.85 & +0.02 & 0.0004 \\
\hline 24 & 5 & 1.0 & 0.94 & 0.93 & +0.10 & 0.0100 \\
\hline 25 & 5 & 1.0 & 0.20 & 0.80 & -0.03 & 0.0009 \\
\hline 26 & 4 & 1.0 & 0.16 & 0.66 & -0.17 & 0.0289 \\
\hline 27 & 3 & 1.0 & 0.16 & 0.66 & -0.17 & 0.0289 \\
\hline
\end{tabular}

シテ絲越體 メ一般二膨火，血管入充盈シ上皮細胞

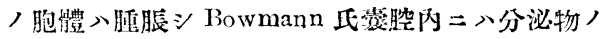

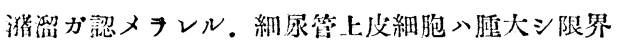
不明显ノモノモフリ，原形質八顆粒狀，絧狀乃至 除北サレテ等胞キ形成シテ虎ルモノモアル。核ハ 一般二染色惡ク斯ル所入管䏶，所在が不明デアル

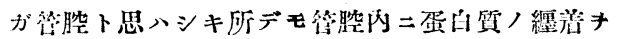
認メル，集合售二ハ楛變キ認メナイ。

斯ル刑臟二就テ II. 虽キ测定シタノ二第10表ノ 第10表「カンタタヂン」注射 Maus 粲內 II.是

\begin{tabular}{|c|c|c|c|c|}
\hline 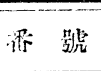 & 匹 数 & $\begin{array}{c}\text { 腎重昷 } \\
\mathrm{g}\end{array}$ & $2 \mathrm{E}$ & $\mathrm{mg} / \mathrm{kg} \mathrm{H}$. \\
\hline 1 & 6 & 1.5 & 0.44 & 1.96 \\
\hline 2 & 5 & 1.0 & 0.28 & 1.30 \\
\hline$\therefore$ & 4 & 1.0 & 0.20 & 0.80 \\
\hline 4 & 7 & 1.5 & 1.20 & 5.21 \\
\hline 5 & 3 & 1.0 & 0.38 & 2.50 \\
\hline 6 & 5 & 1.0 & 0.38 & 2.50 \\
\hline 7 & 5 & 1.0 & 0.34 & 2.00 \\
\hline 8 & 5 & 1.0 & 0.20 & 0.80 \\
\hline 9 & 5 & 1.0 & 0.29 & 1.50 \\
\hline 10 & 5 & 1.0 & 0.34 & 2.00 \\
\hline
\end{tabular}

如クデアッタ.

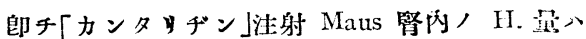
50 匹二就テ見ル $=\mathrm{M} \pm \mathrm{P} . \mathrm{E} .=2.05 \pm 0.051 \mathrm{mg} / \mathrm{hg}$, $\sigma= \pm 1.23, \mathrm{~V}=60$ デアッタ.

\section{2.「硝酸ウラン」}

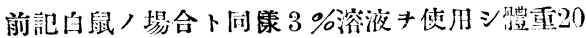
$\mathrm{g}=$ 就 $\neq 0.1 \mathrm{ccc}$ *皮下二注射シ想川更二0.1c.c. ₹注 射スル時入Maus ハ元氣ガナクナ不活潑トナル ガ死二至ヨナイ、故二斯ル狀態ノモノノミキ授殺 シ數匹キ合シテ其ノ孯重最キ $1.0 \mathrm{~g}$ トナシ 1 群卜

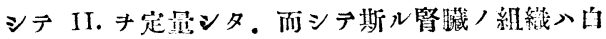

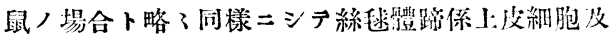

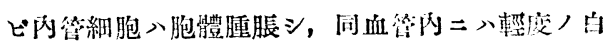
血球ガ集積シ充血八可成り著明デアル． 父 Bow-

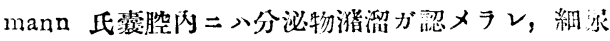
管主部上皮細胞入腫脹ン顆粒乃至穕状ノ物質が認

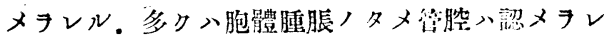

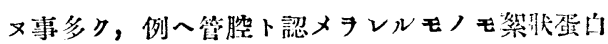

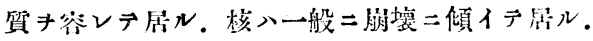

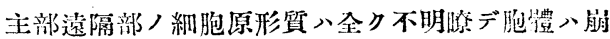


䘫二傾キ上皮細胞核ハ染色ガ惡イ. Henle 氏蹄係

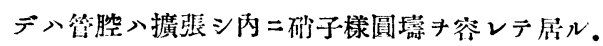
集合得二著變メ酒メヌレナイ。

斯儿腎闪ノII. 是キ测定シタノ二第11表/如ク デアッタ，

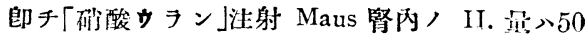
匹二就テ見ル $=\mathrm{M} \pm$ P.E. $=0.35 \pm 0.002 \mathrm{mg} / \mathrm{kg}$ ， の土0.303, $\mathrm{V}=86$ デアッタ.
第11表「矿酸ウヨン」注射 Maus 腎內 H. 别

\begin{tabular}{|c|c|c|c|c|}
\hline 香 號 & 匹 數 & $\begin{array}{c}\text { 䁂重量 } \\
\mathrm{g}\end{array}$ & $2 \mathrm{E}$ & $\mathrm{mg} / \mathrm{kg} \mathrm{II}$. \\
\hline 1 & 5 & 1.0 & 0.08 & 0.39 \\
\hline 2 & 5 & 1.3 & 0.10 & $0.3 t$ \\
\hline 3 & 6 & 1.2 & 0.06 & 0.25 \\
\hline 4 & $\dot{4}$ & 1.0 & 0.10 & 0.34 \\
\hline 5 & 6 & 1.0 & 0.10 & 0.44 \\
\hline 6 & 4 & 1.0 & 0.06 & 0.30 \\
\hline 7 & 5 & 1.0 & 0.10 & 0.44 \\
\hline 8 & 5 & 1.0 & $0.0 \mathrm{~S}$ & 0.39 \\
\hline 9 & 5 & 1.0 & 0.06 & 0.30 \\
\hline 10 & 5 & 1.0 & 0.08 & 0.39 \\
\hline
\end{tabular}

\section{總括並二考察}

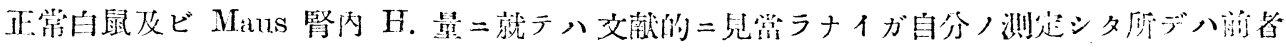

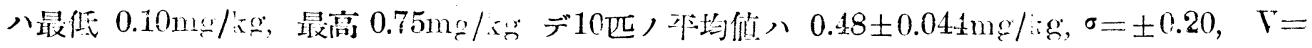

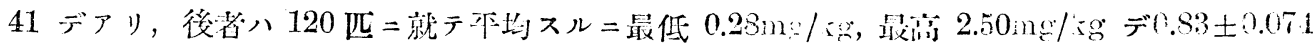

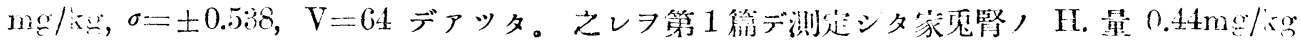

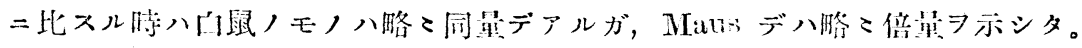

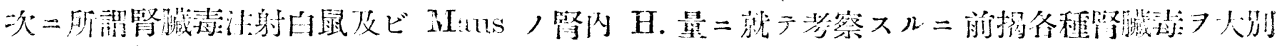

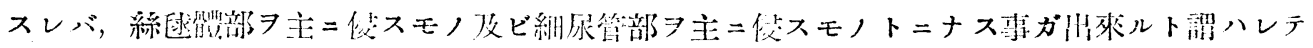

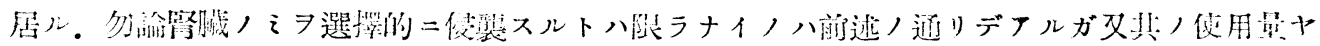

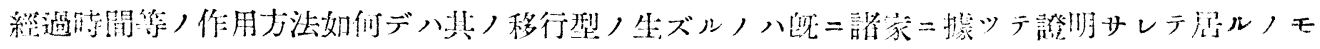

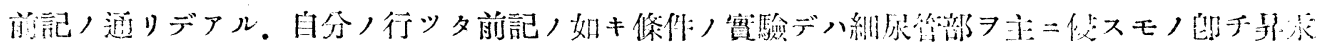

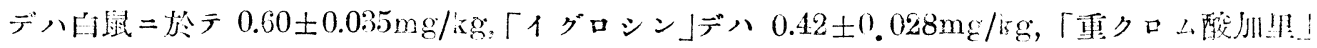

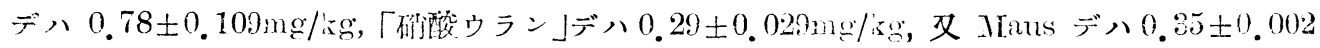

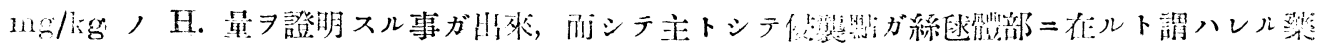

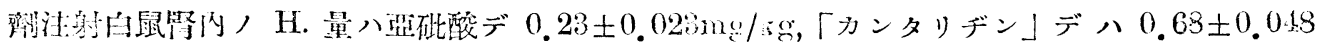

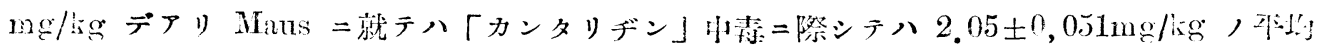

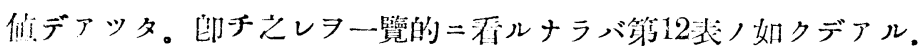

此ノ表カラ分ル如ク H. ノ增量

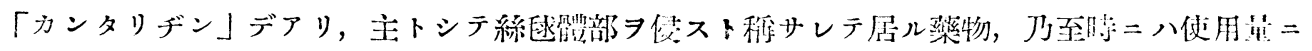

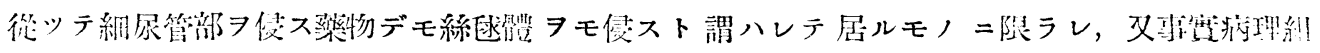

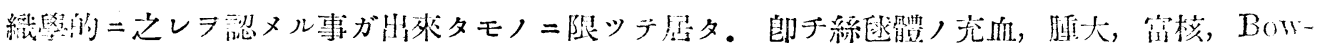

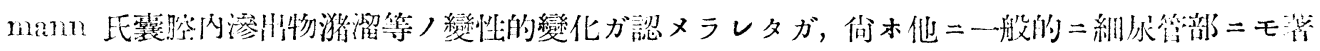

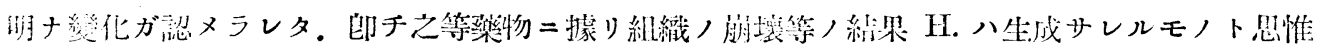

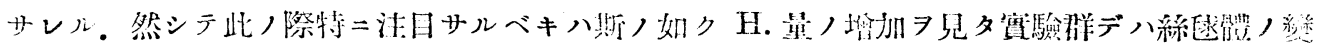

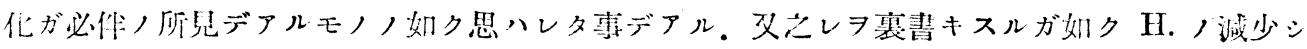


筇

12

表

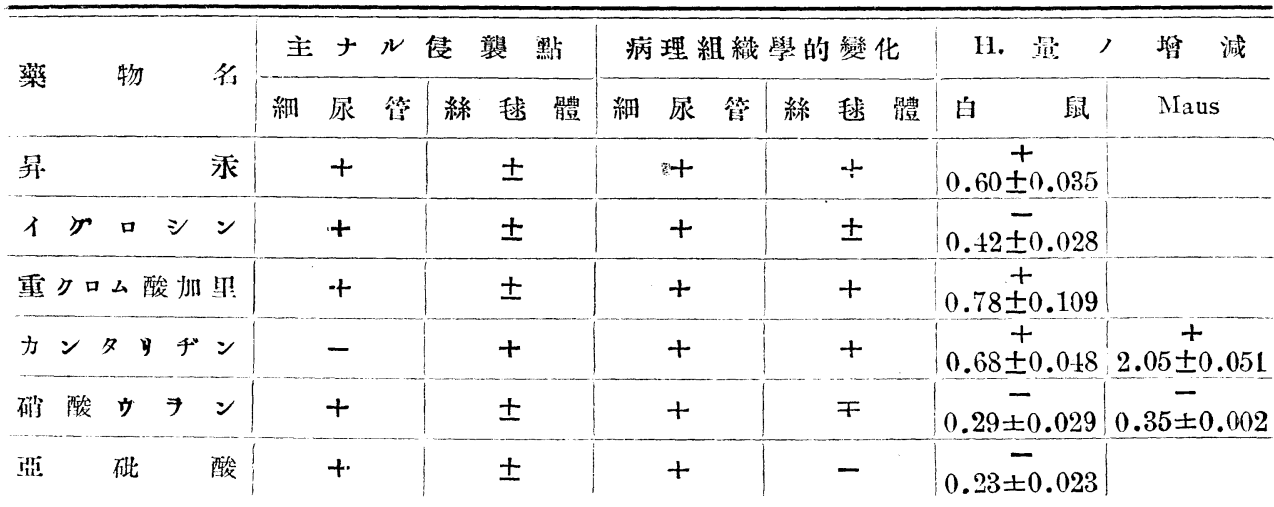

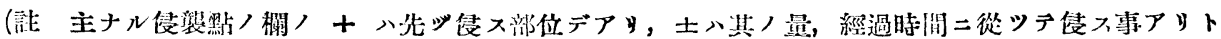

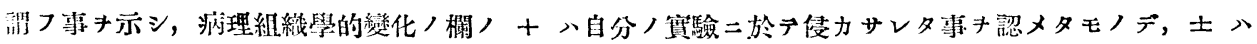

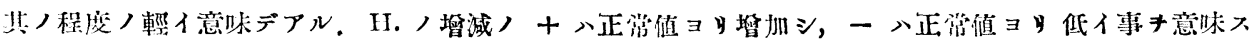
r.)

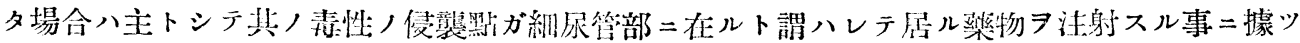

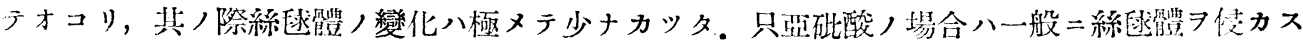

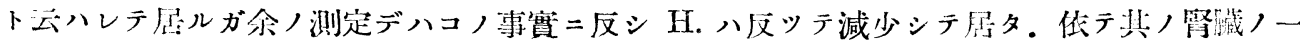

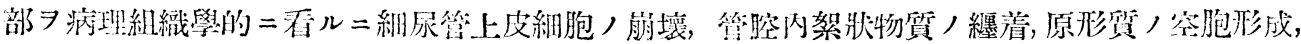

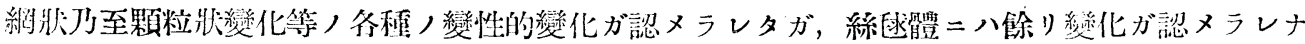
カッッタ.

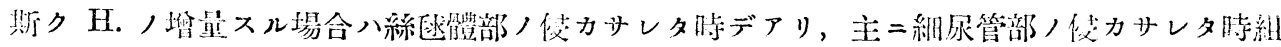

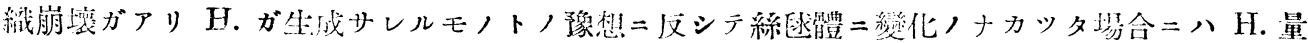

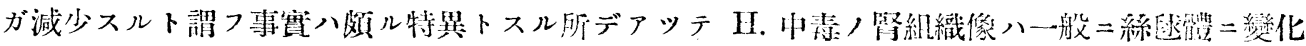

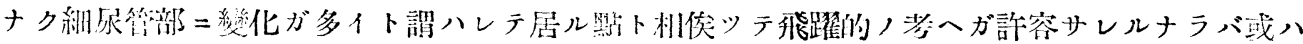

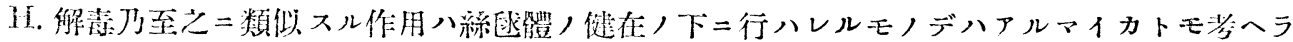

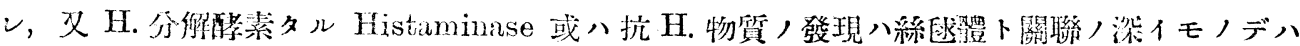
アルマイカト考へラル。

\section{結 論}

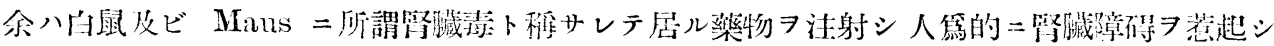

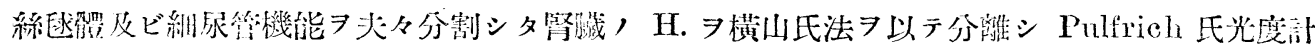

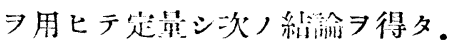

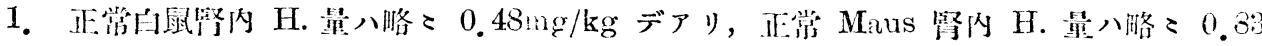
$m g / k g$ デアル.

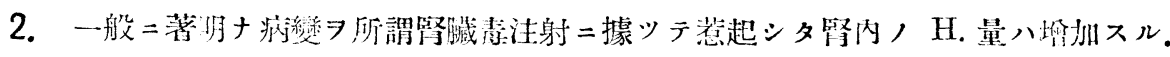




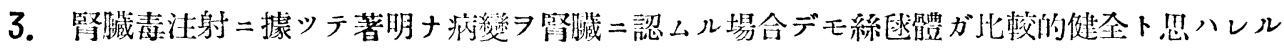
靔內ノ H. 量入反對二減少スル。

擱筆スルニ虽り終始御想篤ナル御指導卜御校閲ナ睗ハタタル恩師並木數授二深謝

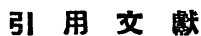

最㷋ノ篇二於テ緾メア゙设表ス。

(昭和18作 9 月 6 日妥付) 